\title{
Nonspecific Induction of $\beta$-lactamase in Enterobacter cloacae
}

\author{
By WOLFGANG CULLMANN, ${ }^{*}$ AXEL DALHOFF ${ }^{2}$ AND \\ WOLFGANG DICK ${ }^{1}$ \\ ${ }^{1}$ Department of Medical Microbiology and Immunology of the Ruhr-Universität Bochum, \\ D-4630 Bochum, FRG \\ ${ }^{2}$ Bayer Research Center, Institute of Chemotherapy, Wuppertal, FRG
}

(Received 2 August 1983; revised 6 December 1984)

\begin{abstract}
Induction of $\beta$-lactamase was monitored in a strain of Enterobacter cloacae exhibiting high resistance to most $\beta$-lactam antibiotics. Large amounts of the enzyme were induced not only in the presence of $\beta$-lactams, but also in the presence of other bicyclic molecules such as folic acid, thiamin, tryptophan or haemin. Moreover, complex media (such as Trypticase soy broth and Schaedler's broth) and various body fluids (serum, pleural fluid and cerebrospinal fluid) also possessed considerable induction potency. Neither 'specific' induction (by $\beta$-lactams) nor 'nonspecific' induction (by other bicyclic compounds) could be augmented by addition of exogenous cAMP. These findings indicate that inducible $\beta$-lactamases deserve more attention, above all with respect to the development of resistance against third-generation cephalosporins.
\end{abstract}

\section{INTRODUCTION}

Since the introduction of the newer $\beta$-lactam antibiotics, chromosomally mediated, inducible $\beta$-lactamases have become increasingly important (Sanders, 1983). It is well established that most $\beta$-lactam antibiotics appear to be affected by these enzymes either by hydrolysis or by the non-hydrolytic barrier mechanism (Gootz \& Sanders, 1983; Sanders, 1983). In some cases, these enzymes are produced constitutively; however, induction generally occurs (Gootz \& Sanders, 1983). Large amounts of enzyme are often produced by strains belonging to the genera Enterobacter, Serratia or Citrobacter, thus leading to a high degree of resistance against a wide variety of $\beta$-lactam antibiotics. As these strains sometimes produce several enzymes, it is of major interest to investigate which structural features of $\beta$-lactam antibiotics may be responsible for enzyme induction, and also whether induction potency can be attributed exclusively to the $\beta$-lactam nucleus. There are several reports in the literature that media or body fluids influence $\beta$-lactamase induction (Bondi et al., 1954; Gootz \& Sanders, 1983). Recently, it was observed that the expression of $\beta$-lactamase was more markedly enhanced in Trypticase soy broth than in Mueller-Hinton broth (Gootz \& Sanders, 1983). Moreover, it could be demonstrated that in animals (granuloma pouch model) large amounts of $\beta$-lactamase were produced - even in those animals that were not treated with $\beta$-lactam antibiotics (Dalhoff, 1982). This was why we investigated whether $\beta$-lactamase induction is restricted to $\beta$-lactam compounds or whether other cyclic compounds also exhibit induction potency.

A preliminary report of some of our findings has already been presented (Cullmann et al., $1983 a$ ).

\section{METHODS}

Strain. $\beta$-Lactamase induction was studied in an Enterobacter cloacae strain (966/81) recently isolated from a clinical specimen. The strain was identified using the API 20 system (API-Bio Mérieux, Nürtingen, FRG).

Determination of minimal inhibitory concentrations. Antibiotic sensitivity was measured by the microdilution procedure with twofold serial dilutions. An inoculum of $5 \times 10^{5}$ bacterial $\mathrm{ml}^{-1}$ was used in all experiments. All minimal inhibitory concentrations were determined in Mueller-Hinton broth (Merck). 
Monitoring of $\beta$-lactamase induction. Isosensitest broth (Oxoid) was used for all induction experiments. A minimal medium was prepared as described elsewhere (Gootz \& Sanders, 1983) containing $\mathrm{K}_{2} \mathrm{HPO}_{4}\left(14 \mathrm{~g}^{-1}\right.$ ), $\mathrm{KH}_{2} \mathrm{PO}_{4}\left(6 \mathrm{~g} \mathrm{l}^{-1}\right), \mathrm{NH}_{4} \mathrm{CO}_{2} \mathrm{CH}_{3}\left(2 \mathrm{~g} \mathrm{l}^{-1}\right), \mathrm{MgSO}_{4}$ (anhydrous) $\left(0.2 \mathrm{gl}^{-1}\right)$ and glucose $\left(10 \mathrm{~g}^{-1}\right)$; the $\mathrm{pH}$ was adjusted to 7·0. Mueller-Hinton broth (Merck), Trypticase soy broth, Brain-heart infusion broth and Schaedler's broth (all from Oxoid) were prepared according to the manufacturer's instructions. One batch of each was used throughout the experiments. For the study of enzyme induction an overnight culture of strain $966 / 81$ was diluted 100 -fold into Isosensitest broth containing the inducer and incubated at $37^{\circ} \mathrm{C}$ with shaking $(120$ r.p.m.).

Enzyme induction was monitored either for $24 \mathrm{~h}$ (samples were taken after 2,3,4,6,8,10,12, 16, and $24 \mathrm{~h}$ ) or for $4 \mathrm{~h}$ (samples were taken after 90,150 , and $240 \mathrm{~min}$ ); in the latter experiments, each assay series was run with inducer concentrations ranging from 20 to $500 \mathrm{mg} \mathrm{ml}^{-1}$; control assays without inducer were included in each series. Cells were harvested at the above-mentioned time intervals by centrifugation at $5000 \mathrm{~g}$ for $10 \mathrm{~min}$ (Christ Minifuge, Osterode, FRG) and washed once with $\mathrm{NaCl}\left(9 \mathrm{~g} \mathrm{l}^{-1}\right)$. The cells were resuspended in a corresponding volume of distilled water and subjected to ultrasonic disruption (Branson Sonic Power-Ultrasonics, Plainview, $\mathrm{NY}$, USA) for $2 \mathrm{~min}$ at $4^{\circ} \mathrm{C}$. Cell debris was removed by centrifugation at $5000 \mathrm{~g}$ for $15 \mathrm{~min}$ at $4{ }^{\circ} \mathrm{C}$. The cleared sonic extracts were immediately frozen at $-20^{\circ} \mathrm{C}$ and analysed within $10 \mathrm{~d}$. The effect on enzyme induction of added cAMP ( $\left.5 \mathrm{mmol}^{-1}\right)$ was concurrently studied in cells grown either in Isosensitest medium containing $10 \mathrm{mg}$ cefoxitin $1^{-1}$ or in Schaedler's broth without drug.

$\beta$-Lactamase assay. The enzyme activity of cleared sonic extracts was determined by a spectrophotometric assay. For this purpose the chromogenic cephalosporin compound Centa was employed; it is less affected by $\mathrm{pH}$ and the protein matrix than nitrocefin (Jones et al., 1982; O'Callaghan et al., 1972). Increase in absorbance was monitored at $412 \mathrm{~nm}$ for $2 \mathrm{~min}$. All experiments were carried out in $0.05 \mathrm{M}$-triethanolamine buffer adjusted to pH 7.6 with a final substrate concentration of $3.3 \times 10^{-4} \mathrm{M}$ at $37^{\circ} \mathrm{C}$. Total protein content of the cell-free supernatants was determined by the method of Markwell et al. (1978). Enzyme activity was expressed in units (mg protein $)^{-1}$; one enzyme unit is defined as the amount of enzyme hydrolysing $1 \mu$ mol substrate $\min ^{-1}$.

Isoelectric focusing was performed as previously described (Cullmann et al., 1982). Gel sheets containing ampholine pH 3.5-9.5 were used (LKB). Enzyme activity was detected with the chromogenic cephalosporin nitrocefin because of its marked colour change (O'Callaghan et al., 1972). In these experiments the strain was grown for $4 \mathrm{~h}$ in the presence of the inducers.

Reagents. The antibiotics used in this study were obtained from the following sources: cefoxitin and $\mathrm{N}$ formimidoylthienamycin (imepenem) from Merck, Sharp \& Dohme (Munich, FRG); moxalactam (latamoxef) from Eli Lilly (Giessen, FRG); mezlocillin from Bayer (Leverkusen, FRG); azthreonam (aztreonam) from Squibb-Heydn (Munich, FRG); clavulanic acid from Beecham-Wuelfing (Neuss, FRG); the penem compound Sch 29482 from Byk-Essex (Munich, FRG); fusidic acid from Thomae Pharm. (Biberach a.d. Riss, FRG); 6aminopenicillanic acid from Fluka (Buchs, Switzerland). The chromogenic cephalosporins were kindly supplied by Hoechst, Frankfurt, FRG (Centa) and by Cascan-Glaxo, Wiesbaden, FRG (nitrocefin).

cAMP was from Boehringer, and all other reagents, of analytical grade, were from Sigma.

\section{RESULTS}

Susceptibility of E. cloacae strain $966 / 81$ to antimicrobial compounds. The following minimal inhibitory concentrations were obtained: $256 \mathrm{mg} \mathrm{l}^{-1}$ for cefoxitin; $128 \mathrm{mg} \mathrm{l}^{-1}$ for 6-aminopenicillanic acid and mezlocillin; $64 \mathrm{mg}^{-1}$ for moxalactam, azthreonam and clavulanic acid; $2 \mathrm{mg} \mathrm{l}^{-1}$ for the penem Sch 29482 ; and $1 \mathrm{mg} \mathrm{l}^{-1}$ for $N$-formimidoylthienamycin.

Influence of various media on $\beta$-lactamase induction. To discover whether various media influenced enzyme inductions, the following were investigated: Isosensitest, Mueller-Hinton broth, Trypticase soy broth, Brain-heart infusion broth, Schaedler's broth, and the minimal medium described in Methods (Fig. 1). In all these experiments no $\beta$-lactam antibiotics were added. Schaedler's broth had by far the greatest induction potency, exceeding that of Trypticase soy broth, Mueller-Hinton broth, and Brain-heart infusion broth. On the other hand, the induction potency of Isosensitest broth was only marginal as compared to the minimal medium, in which good growth also occurred (Fig. 1). A repeat of the experiment three months later revealed negligible discrepancies between the two assay series: $\beta$-lactamase levels were reproducible with about $5 \%$ error. Isoelectric focusing confirmed the above findings (see Fig. $4 b$ ). The increase of induction potency was associated with the appearance of further bands. The poorly visible bands were probably 'satellite bands' (Matthew et al., 1975). At present this phenomenon cannot be entirely explained (Simpson \& Plested, 1983).

Specific induction of $\beta$-lactamases by various $\beta$-lactam compounds. In order to compare enzyme induction by the media with that of $\beta$-lactam antibiotics, eight different agents were evaluated. 


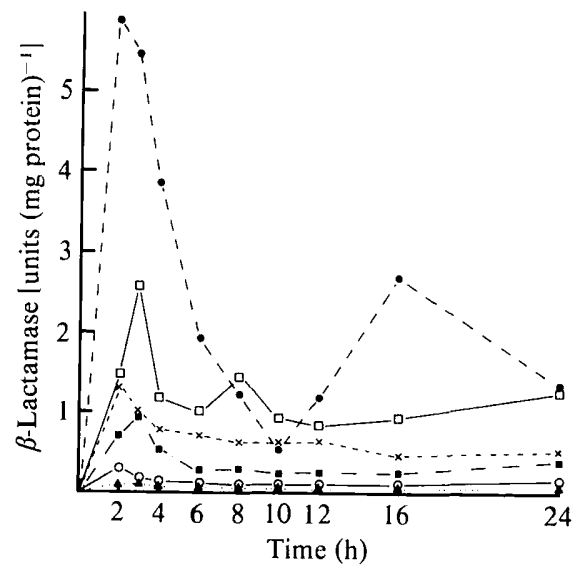

Fig. 1. 'Nonspecific' induction of $\beta$-lactamase in $E$. cloacae strain $966 / 81$ by culture media. Enzyme activity was quantified with the chromogenic cephalosporin Centa. 0 , Schaedler's broth; $\square$, Trypticase soy broth; $\times$, Mueller-Hinton broth; $\square$, Brain-heart infusion broth; $\bigcirc$, Isosensitest broth; $\Delta$, minimal medium of Gootz \& Sanders (1983) (control).
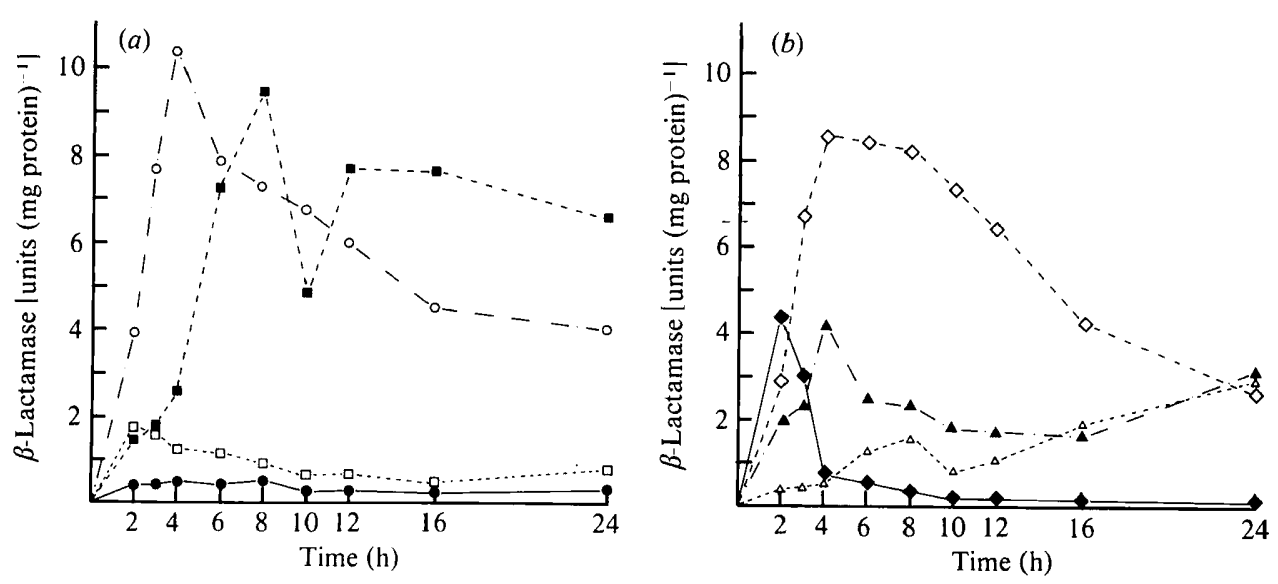

Fig. 2. Induction of $\beta$-lactamase in $E$. cloacae strain $966 / 81$ by the addition of various $\beta$-lactam compounds. All experiments were carried out in Isosensitest medium. (a) 0,6 -Aminopenicillanic acid (10 $\left.\mathrm{mg} \mathrm{1}^{-1}\right) ; \square$, moxalactam $\left(10 \mathrm{mg} \mathrm{1}^{-1}\right) ; \square$, cefoxitin $\left(10 \mathrm{mg} \mathrm{l}^{-1}\right) ; 0$, mezlocillin $\left(10 \mathrm{mg} \mathrm{l}^{-1}\right)$. (b) $\diamond$, Penem Sch $29482\left(0.5 \mathrm{mg} \mathrm{l}^{-1}\right) ; \diamond, N$-formimidoylthienamycin $\left(0.5 \mathrm{mg} \mathrm{l}^{-1}\right) ; \Delta$, clavulanic acid $\left(10 \mathrm{mg} \mathrm{l}^{-1}\right) ; \Delta$, azthreonam $\left(10 \mathrm{mg} \mathrm{l}^{-1}\right)$.

Usually the compound was added at a concentration of $10 \mathrm{mg}^{-1}$ to the Isosensitest medium; $0.5 \mathrm{mg} \mathrm{l}^{-1}$ was added in the case of $N$-formimidoylthienamycin and the penem compound Sch 29 482. 6-Aminopenicillanic acid, the oxacephem compound moxalactam, and the penem Sch 29482 exceeded by about twofold, and clavulanic acid equalled, the induction potency of Schaedler's broth (Fig. $2 a, b$ ). Cefoxitin, the monobactam azthreonam and mezlocillin were poorer inducers. In the case of $N$-formimidoylthienamycin, a rapid increase followed by a strong decrease of enzyme activity was observed (Fig. $2 b$ ). Isolectric focusing revealed enzyme patterns confirming the above findings (see Fig. $4 a$ ). Assays at different time intervals exhibited similar enzyme patterns.

Induction potency of various cyclic compounds. To establish which structural features might be responsible for 'nonspecific' induction of $\beta$-lactamase in $E$. cloacae strain $966 / 81$, a variety of cyclic compounds was screened (Table 1). Tryptophan, folic acid, thiamin and haemin were inducers, whereas other amino acids such as phenylalanine or histidine were not. All inducers 


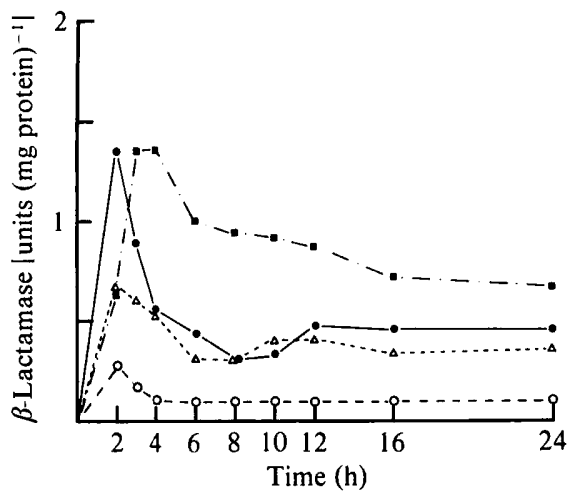

Fig. 3. Induction of $\beta$-lactamase in $E$. cloacae strain $966 / 81$ in the presence of various body fluids, each at $25 \%(\mathrm{v} / \mathrm{v})$., Heat-inactivated serum; $\square$, heat-inactivated pleural fluid; $\triangle$, cerebrospinal fluid; $O$, control assay in Isosensitest broth. $\beta$-Lactamase was quantified with the chromogenic compound Centa.

Table 1. Nonspecific induction of $\beta$-lactamase in Enterobacter cloacae strain $966 / 81$

\begin{tabular}{|c|c|c|c|c|}
\hline \multirow[b]{2}{*}{ Inducer } & \multirow[b]{2}{*}{$\begin{array}{l}\text { Concn } \\
\left(\mathrm{mg} \mathrm{1}^{-1}\right)\end{array}$} & \multicolumn{3}{|c|}{$\beta$-Lactamase activity relative to control assay $(=1 \cdot 0)$} \\
\hline & & $\begin{array}{l}\text { after } \\
90 \mathrm{~min}\end{array}$ & $\begin{array}{c}\text { after } \\
150 \mathrm{~min}\end{array}$ & $\begin{array}{c}\text { after } \\
240 \mathrm{~min}\end{array}$ \\
\hline \multirow{3}{*}{ Tryptophan } & 20 & $1 \cdot 19$ & 1.06 & 0.92 \\
\hline & 100 & $1 \cdot 12$ & 1.43 & 1.96 \\
\hline & 500 & $1 \cdot 01$ & 1.57 & $3 \cdot 77$ \\
\hline Indol-3-carbinol & 500 & $1 \cdot 15$ & $0 \cdot 38$ & $0 \cdot 31$ \\
\hline Indican & 500 & $1 \cdot 02$ & $1 \cdot 03$ & 0.61 \\
\hline Phenylalanine & 500 & $1 \cdot 50$ & $1 \cdot 11$ & 1.02 \\
\hline Histidine & 500 & $1 \cdot 78$ & 1.05 & $1 \cdot 08$ \\
\hline Adenine & 500 & $1 \cdot 27$ & $1 \cdot 03$ & 0.91 \\
\hline Riboflavin & 100 & $0 \cdot 28$ & $0 \cdot 25$ & $0 \cdot 10$ \\
\hline \multirow[t]{3}{*}{ Thiamin } & 20 & 0.96 & 0.93 & $1 \cdot 60$ \\
\hline & 100 & $1 \cdot 12$ & $1 \cdot 15$ & $2 \cdot 56$ \\
\hline & 500 & $1 \cdot 10$ & $1 \cdot 25$ & $4 \cdot 90$ \\
\hline \multirow[t]{3}{*}{ Folic acid } & 20 & 0.94 & 0.93 & 1.80 \\
\hline & 100 & $1 \cdot 00$ & $1 \cdot 10$ & $3 \cdot 13$ \\
\hline & 500 & $1 \cdot 27$ & $1 \cdot 30$ & $3 \cdot 70$ \\
\hline \multirow[t]{2}{*}{ Haemin } & 20 & 0.97 & $1 \cdot 10$ & 2.95 \\
\hline & 100 & $1 \cdot 00$ & $1 \cdot 10$ & $3 \cdot 20$ \\
\hline 2-Aminothiazole & 100 & 1.08 & $1 \cdot 11$ & 0.99 \\
\hline Thiophene & 500 & 1.06 & 0.93 & 0.96 \\
\hline Piperazine & 100 & 1.04 & 0.96 & $1 \cdot 03$ \\
\hline Menadione & 25 & 1.04 & 0.93 & 0.96 \\
\hline Cortisone & 100 & 0.85 & 0.68 & 0.73 \\
\hline $17 \alpha$-Hydroxyprogesterone & 100 & 0.73 & $1 \cdot 16$ & $1 \cdot 37$ \\
\hline$\beta$-Oestradiol & 100 & 0.73 & 0.88 & 1.59 \\
\hline Cholecalciferol $\left(\mathrm{D}_{3}\right)$ & 100 & 1.04 & 0.95 & 1.40 \\
\hline Fusidic acid & 100 & 0.81 & 0.58 & 0.49 \\
\hline
\end{tabular}

showed a good correlation between their concentration and their induction potency. Addition of riboflavin and fusidic acid even resulted in a decrease of enzyme activity (Table 1). Cyclic molecules (such as thiophene, 2-aminothiazole, piperazine), which are often part of side-chains of $\beta$-lactams, revealed no induction potency. Although tryptophan was an inducer, its analogues indole-3-carbonol and indican were not (Table 1).

Enzyme induction by various body fluids. From the above-mentioned findings it seemed likely that body fluids may induce $\beta$-lactamases. When $25 \%(\mathrm{v} / \mathrm{v})$ of heat-inactivated serum or pleural 


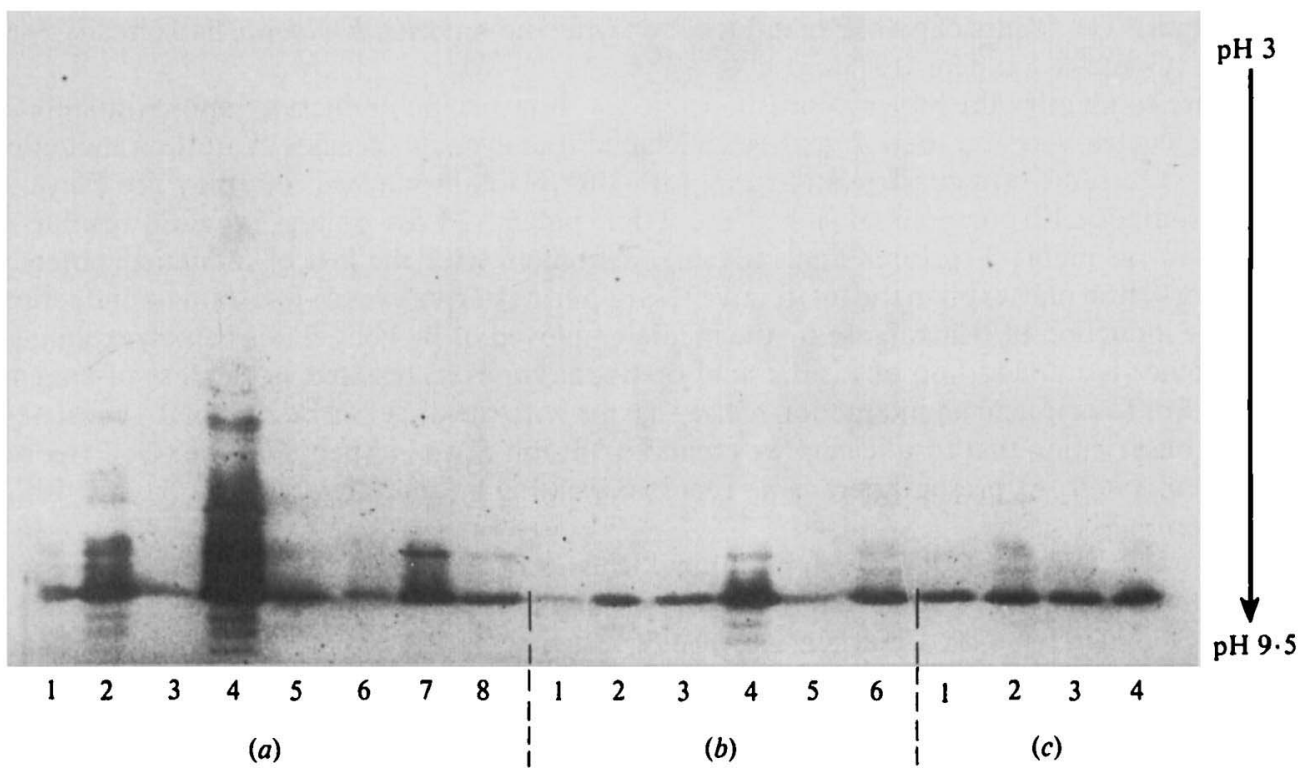

Fig. 4. Isoelectric focusing of inducible $\beta$-lactamase in $E$. cloacae $966 / 81$. (a) The following compounds served as inducers: 1 , mezlocillin $\left(10 \mathrm{mg} \mathrm{l}^{-1}\right) ; 2$, 6-aminopenicillanic acid $\left(10 \mathrm{mg}^{-1}\right) ; 3$, cefoxitin (10 $\left.\mathrm{mg} \mathrm{l}^{-1}\right) ; 4$, moxalactam $\left(10 \mathrm{mg} \mathrm{l}^{-1}\right) ; 5$, clavulanic acid $\left(10 \mathrm{mg} \mathrm{l}^{-1}\right) ; 6$, azthreonam $\left(10 \mathrm{mg} \mathrm{l}^{-1}\right)$; 7, penem Sch $29482\left(0.5 \mathrm{mg} \mathrm{l}^{-1}\right) ; 8, N$-formimidoylthienamycin $\left(0.5 \mathrm{mg} \mathrm{l}^{-1}\right)$.

(b) The following media served as inducers : 1, minimal medium; 2, Mueller-Hinton broth; 3, Brainheart infusion broth; 4, Schaedler's broth; 5, Isosensitest broth; 6, Trypticase soy broth.

(c) Induction occurred in the presence of the following body fluids $(25 \%, \mathrm{v} / \mathrm{v}) ; 1$, serum; 2 , pleural fluid; 3 , cerebrospinal fluid; 4 , urine.

fluid was added to the Isosensitest medium, enzyme activities comparable to those obtained with cefoxitin as the inducer resulted (Fig. 3). Addition of cerebrospinal fluid resulted in somewhat lower enzyme activity (Fig. 3), as did addition of urine (data was not shown). The results of isoelectric focusing again corresponded well with these findings (Fig. 4).

Effect of cAMP on enzyme induction. In many cases enzyme induction is subject to catabolite repression. Thus we evaluated the effect of added cAMP $\left(5 \mathrm{mmol} \mathrm{1}^{-1}\right)$ on $\beta$-lactamase induction. The enzyme was induced either by addition of cefoxitin $\left(10 \mathrm{mg}^{-1}\right)$ or by further growth in Schaedler's broth. In both experiments, cAMP did not affect $\beta$-lactamase induction (data not shown).

\section{DISCUSSION}

To the best of our knowledge, 'nonspecific' induction of $\beta$-lactamase in $E$. cloacae has not been described in the literature by other workers. Some 20 years ago, there was a report that considerable penicillinase activity could be detected in kidney homogenates of Staphylococcus aureus-infected mice, which had not received penicillin (Dineen, 1961). The relevance of the media employed was pointed out as early as 1954 (Bondi et al., 1954). These authors observed that $S$. aureus penicillinase was best expressed either in a casein hydrolysate or in an amino acid medium containing cyclic amino acids. However, they did not assume an induction, but an inhibition of enzyme production by aliphatic amino acids. Moreover, high concentrations of bacitracin were shown to induce $\beta$-lactamase synthesis in Bacillus cereus 569 (Citri, 1978).

Recently, marked discrepancies in $\beta$-lactamase production depending on the nutrient medium employed were observed for E. cloacae (Gootz \& Sanders, 1983). Cefoxitin (a cephamycin derivative) proved to be a more potent inducer in Trypticase soy broth than in Mueller-Hinton broth. In most cases the inducing effect appears transient; this has to be ascribed to the stability of the $\beta$-lactam compound against breakdown by the induced enzyme (Minami et al., 1980; Gootz \& Sanders, 1983) or to the metabolic removal of the inducer 
(tryptophan). The failure of cAMP to influence enzyme induction in E. cloacae had already been reported (Gootz \& Sanders, 1983).

In order to identify the molecules responsible for 'nonspecific' induction, approximately 20 cyclic molecules were screened. It can be concluded that cyclic molecules exhibiting induction potency have some structural relationship with the $\beta$-lactam nucleus, i.e. they are bicyclic, whereas monocyclic compounds lacked induction potency. Loss of the aliphatic residue of tryptophan (in indole-3-carbinol and indican) was linked with the loss of induction potency. This observation may explain the ineffectiveness of purine derivatives in $\beta$-lactamase induction. Thus, the induction of $\beta$-lactamase by the media employed or by body fluids can be explained. On the other hand, addition of fusidic acid or riboflavin even resulted in the loss of enzyme activity. For fusidic acid an interaction of the enzyme with the drug can be assumed - consistent with the observation that fusidic acid was found to inhibit $S$. aureus penicillinase (Godtfredsen $\&$ Jahnsen, 1969). At present there is no report indicating an interaction of riboflavin with $\beta$ lactamases.

In a study on 78 ampicillin-resistant clinical isolates of E. cloacae, Serratia marcescens and Citrobacter freundii, 'nonspecific' induction of large amounts of $\beta$-lactamase could be detected in 24 isolates associated with a marked increase of resistance against most $\beta$-lactam compounds (Cullmann et al., 1983b). With respect to in vivo conditions, recently published observations deserve attention: production of large amounts of $\beta$-lactamase could be detected in Morganella morganii independently of the administration of $\beta$-lactam antibiotics (Dalhoff, 1982). As the bacteria grown in haemorrhagic exudate were directly examined without subculture, it can be assumed that $\beta$-lactamase was produced in vivo.

At present many questions remain open, e.g. there is no information available as to whether chromosomally mediated enzymes interact with other bicyclic molecules than $\beta$-lactams (such as the inducers tryptophan, thiamin, etc.).

\section{REFERENCES}

Bondi, A., De Saint Phalle, M., Kornblum, J. \& MoAT, A. G. (1954). Factors influencing the synthesis of penicillinase by Micrococcus pyogenes. Archives of Biochemistry and Biophysics 53, 348-353.

CITRI, Y. (1978). Induction of penicillinase by bacitracin. Biochemical and Biophysical Research Communications 80, 573-579.

Cullmann, W., Flensberg, Th., Opferkuch, W., Stieglitz, M.\& Wiedemann, B. (1982). Correlation of $\beta$-lactamase production and resistance to $\beta$-lactam antibiotics in Enterobacteriacae. Zentralblatt für Bakteriologie (Abteilung I, Originale A) 252, 480-489.

Cullmann, W., Dick, W. \& Dalhoff, A. (1983a). Nonspecific induction of $\beta$-lactamase in Enterobacter cloacae. Journal of Infectious Diseases 148, 765.

Cullmann, W., Opferkuch, W. \& Stieglitz, M. $(1983 b)$. Relation between $\beta$-lactamase production and antimicrobial activity: comparison of the new compound HR 810 with cefotaxime. European Journal of Clinical Microbiology 2, 350-352.

DALHOFF, A. (1982). Interaction of Mezlocillin and Cefoxitin against Proteus morganii in the granuloma pouch model. European Journal of Clinical Microbiology 1, 243-247.

DINEEN, P. (1961). The in-vivo production of penicillinase by hemolytic Staphylococcus aureus. Journal of Immunology 86, 496-504.

Godtrredsen, W. O. \& Jahnsen, S. (1969). Fusidanetype antibiotics. Process Biochemistry 4, 11-17.

Gootz, R. D. \& SANders, C. C. (1983). Characterization of $\beta$-lactamase induction in Enterobacter cloacae. Antimicrobial Agents and Chemotherapy 23, 91-97.
JoNes, R. N., Wilson, H. W., Novick, W. J., JR, BARRY, A. L. \& THORNSBERRY, C. (1982). In-vitro evaluation of Centa $^{R}$, a new beta-lactamase susceptible chromogenic cephalosporin reagent. Journal of Clinical Microbiology 15, 954-958.

Markwell, M. A. K., Hass, S. M., Bieber, L. L. \& TOLBERT, N. E. (1978). A modification of the Lowry procedure to simplify protein determinations in membrane and lipoprotein samples. Analytical Biochemistry 87, 206-210.

Matthew, M., Harris, A. M., Marshall, M. J. \& Ross, G. W. (1975). The use of analytical isoelectric focusing for detection and identification of $\beta$ lactamases. Journal of General Microbiology 88, 169178.

Minami, S., Yotsuji, A., Inoue, M. \& Mrtsuhashi, S. (1980). Induction of $\beta$-lactamase by various $\beta$-lactam antibiotics in Enterobacter cloacae. Antimicrobial Agents and Chemotherapy 18, 382-385.

O'Callaghan, C. H., Morris, A., Kirby, S. M. \& SHINGLER, A. H. (1972). Method for detection of $\beta$ lactamases by using a chromogenic cephalosporin substrate. Antimicrobial Agents and Chemotherapy 1, 283-288.

SANDERs, C. C. (1983). Novel resistance selected by the new expanded-spectrum cephalosporins: a concern. Journal of Infectious Diseases 147, 585-589.

Simpson, I. N. \& Plested, S. J. (1983). The origin and properties of $\beta$-lactamase satellite bands seen in isoelectric focusing. Journal of Antimicrobial Chemotherapy 12, 127-132. 